\title{
Selection of sites for the in situ conservation of four traditional leafy vegetables consumed in Benin
}

\author{
K. ADÉOTI ${ }^{1}$, A. DANSI ${ }^{2,3^{*}}$, L. AHOTON ${ }^{4}$, B. KPÈKI ${ }^{4}$, B. C. AHOHUENDO ${ }^{4}$, \\ A. AHANCHÉDÉ ${ }^{4}$, R. VODOUHË ${ }^{5}$, J. D. HOUNHOUIGAN ${ }^{6}$ and A. SANNI ${ }^{1}$ \\ ${ }^{1}$ Laboratory of Biochemistry and Molecular Biology, Faculty of Sciences and Technology (FAST), University \\ of Abomey-Calavi (UAC), P.O. Box 526 Cotonou, Benin. \\ ${ }^{2}$ Genetic Resources Unit (GRU), Laboratory of Genetics and Biotechnology, Faculty of Science and \\ Technology (FAST), University of Abomey-Calavi (UAC), P.O. Box 526 Cotonou, Benin. \\ ${ }^{3}$ Crop, Aromatic and Medicinal Plant Biodiversity Research and Development Institute (IRDCAM),071 P.O. \\ Box 28, Cotonou, Benin. \\ ${ }^{4}$ Department of Plant Production, Faculty of Agriculture (FSA), University of Abomey-Calavi (UAC), P.O. Box \\ 526 Cotonou, Benin. \\ ${ }^{5}$ Biodiversity International, Office for West and Central Africa, 08 P.O. Box 0932, Cotonou, Benin. \\ ${ }^{6}$ Department of Nutrition and Food Sciences, Faculty of Agriculture (FSA), University of Abomey-Calavi \\ (UAC), P.O. Box 526 Cotonou, Benin. \\ * Corresponding author, E-mail: adansi2001@gmail.com
}

\begin{abstract}
Acmella uliginosa, Ceratotheca sesamoides, Justicia tenella and Sesamum radiatum are four traditional leafy vegetables which are widely consumed in Benin. In order to document their origin, folk nomenclature, geographical distribution and ecology and to select adequate zones for in situ conservation of their genetic resources, 118 villages were randomly selected and surveyed throughout the country using a participatory research approach. All the species apart from Ceratotheca sesamoides were reported by farmers as introduced in Benin at different periods. The folk nomenclature comprising 93 different names is based on nine key criteria of variable frequencies according to the species. The geographical distribution maps revealed that the species under study are unequally distributed. Indeed, A. uliginosa is found exclusively in the northwest, $J$. tenella in the northeast and partially in the centre while S. radiatum and Ceratotheca sesamoides were found almost everywhere in Benin. Results from multivariate analysis combined with geographical distribution maps of the species and the soil and climate maps of Benin, leaded to the selection of the Northwest and of the Northeast regions as the appropriate conservation zones for the four species. Molecular analysis was recommended as it can help in describing genetic diversity and consequently in identifying additional sites for the widely spread species Sesamum radiatum and Ceratotheca sesamoides.

(C) 2009 International Formulae Group. All rights reserved.
\end{abstract}

Keywords: Folk nomenclature, biodiversity, geographical distribution, site selection, in situ conservation, Benin.

\section{INTRODUCTION}

Traditional Leafy Vegetables (TLVs) are plants whose leaves (including immature green pod and flowers) are socially accepted, used and consumed by the local populations (Dansi et al., 2008a). They are rich in fibres, 
vitamins and minerals such as carotene (provitamin A), ascorbic acid, riboflavin, iron, iodine, calcium, etc. (Chweya and Eyzaguirre, 1999; Odhav et al., 2007; Mensah et al., 2008). In addition to their high concentration in micronutrients, vegetables provide little dietary energy, making them valuable in energy limited diets. The fibre they content has been reported to have beneficial effects on blood cholesterol and aids in the prevention of large bowel diseases, while in diabetic subjects, they improve glucose tolerance (Odhav et al., 2007; Mensah et al., 2008). Throughout the world and in West Africa in particular, quite a large number of TLVs have long been known and reported to have health protecting properties and uses (Odhav et al., 2007; Mensah et al., 2008; Chweya and Eyzaguirre, 1999; Shippers, 2002; AbukutsaOnyango, 2004; Francisca and Eyzaguirre, 2007; Dansi et al., 2008a, 2009a).

In Benin, TLVs occur as cultivated and semi-cultivated crops or weedy and wild plants, with ecological, social and cultural values, playing a significant role in the daily food and nutritional requirements of local people not only in rural areas, but also and increasingly in urban areas. A biodiversity inventory and documentation survey recently conducted on traditional leafy vegetables throughout the country revealed a total of 187 plant species belonging to 141 genera and 52 families (Dansi et al., 2008a, 2008b, 2009a). Out of the species inventoried, 18 having local and/or national importance were identified, among which Acmella uliginosa (L.) Jansen, Ceratotheca sesamoides Endl., Justicia tenella (Nees) T. Anderson and Sesamum radiatum $\mathrm{L}$. were found to be of paramount interest. Indeed, Acmella uliginosa is used as a nutraceutical and believed, apart from its nutritional value, to bear special medicinal properties. It is a medicine which facilitates the elimination of blood clots in women after delivery and stimulates milk production with breast-feeding mothers (Dansi et al., 2008a). Contrary to the seasonally used leafy vegetables, Sesamum radiatum and Ceratotheca sesamoides are available all year round. The first one is cultivated and the second one is harvested from the wild but both of these species can be collected at the time of plenty, sun dried, stored in traditional containers such as gourds and further used when needed. Moreover, these two TLVs are known, to give stoutness and facilitate good growth, dentition and bones' solidification in children when regularly consumed (Dansi et al., 2008a). Justicia tenella, although with no reported medicinal value, is widely cultivated in home gardens and consumed mainly in the Bariba cultural area which spreads over one third of the country.

In order to promote the production, domestication, conservation, marketing and utilization of these four species of high nutritional/medicinal importance for the local communities, a multidisciplinary and multiinstitutional research project has been recently launched by the University of Abomey-Calavi (UAC). The present study was undertaken in order to:

- Document their origin and understand their folk nomenclature,

- Draw their geographical distribution maps and clearly describe their ecology,

- Select appropriate zones for the in situ conservation of the genetic resources of these species.

\section{MATERIALS AND METHODS}

\section{Presentation of the study zone}

The present study was implemented in the Republic of Benin, situated in West Africa between latitudes $6^{\circ} 10^{\prime}$ and $12^{\circ} 25^{\prime}$ and longitudes $0^{\circ} 45^{\prime}$ and $3^{\circ} 55^{\prime}$. The profile of the country is an undulating plateau except for a few scattered hills in the centre and the north. The altitude varies from sea level to 400-650 $\mathrm{m}$ in the northwest, where the Atacora chain is the outstanding feature. Four major groups of soils can be distinguished, according to Adam and Boko (1993): (1) ferrallitic soils covered by semi-deciduous forest, (2) ferruginous soils covered by dry forest, woodland, and savannah, (3) vertisols in the depression of Lama covered by a particular type of semi- 
deciduous forest, and (4) hydromorphic soils covered by swamp and riparian forest.

The average annual rainfall varies from 900 to $1300 \mathrm{~m}$. Its lowest values (900-950 $\mathrm{mm}$ ) are recorded in the southwest and in the far north. The highest rainfalls (1200-1300 $\mathrm{mm}$ ) are confined to southeast Benin along the Bassila-Djougou tract. The average annual temperature ranges from 26 to $28{ }^{\circ} \mathrm{C}$ and can exceptionally reach $35-40{ }^{\circ} \mathrm{C}$ in some northern localities such as Kandi and Malanville. As in most West-African countries, the climate is primarily determined by the annual cycle of the "Inner Tropical convergence Zone" (ITCZ). Three climates zones can broadly be distinguished (Akoègninou et al., 2006): (1) From the coast up to $7^{\circ}-7^{\circ} 30^{\prime} \mathrm{N}$, the climate is subequatorial with two rainy seasons alternating with a long dry season (December-February), and a short dry season (July-August), which rarely exceeds two months, (2) Between the latitudes $7^{\circ}-7^{\circ} 30^{\prime}$ and $9^{\circ}$, the climate becomes subhumid or subsudanian with a tendency to a pattern made of one rainy season and one dry season, (3) The northern section is characterised by a Sudanian climate with a unimodal rainfall regime. The type of this Sudanian climate encountered in the northwest is called Atacorian climate (Akoègninou et al., 2006).

Benin's southern part belongs to the Dahomey gap, which is the dry wedge that separates the West African rain forest belt into the upper Guinea and Lower Guinea /Congolian Forest Blocks (White 1993). As a result, this part of the country (from the coast up to c. $7^{\circ} 30^{\prime} \mathrm{N}$ ) consists of savannah, grassland, farmland, and fallow intermingled with small islands of closed forest (semideciduous and swamp forests). From $c a$. $7^{\circ} 30^{\prime} \mathrm{N}$ to $12^{\circ} 25^{\prime} \mathrm{N}$, the natural vegetation is essentially made of a patchwork of a woodlands and savannahs with belts of riparian forest along rivers.

\section{Sites selection and survey}

In order to draw a concise geographical distribution of a plant species at the country level, a great number of villages located in different agroecological zones and spread out all over the country should be considered. For these reasons, 118 villages (Table 1) belonging to diverse ethnical and agro-ecological (humid, semi arid, arid) zones (Dansi et al., 2008a, 2009a) were randomly selected and surveyed (Figure 1). Data were collected during expeditions to different sites, through the application of Participatory Research Appraisal tools and techniques such as direct observation, group discussions, individual interviews and field visits using a questionnaire, according to Kamara et al. (1996), Defoer et al. (1997), Chweya and Eyzaguirre (1999), Adoukonou-Sagbadja et al. (2006) and Dansi et al. (2008a, 2008b, 2009a). Interviews were conducted with the help of interpreters from each area. As TLVs are mainly a women's affair; women local organisations were involved in the study in each site, in order to facilitate precise data collection. Prior to group meeting, farmers were requested in advance to bring samples of the species under study and, if any, samples of their known diverse forms. Specific information about the area (agro-ecological zone, name of location, name of sub-location, name of village, ethnic group) were first collected after detailed presentation of the research objectives to the farmers. Then, farmers were asked to display the different types of the species and their variability as known in their village if any. Through discussion, key information was recorded on each one of the species under study. These are: vernacular name and meaning, origin, preferred habitat, intraspecific diversity and specific uses (known medicinal properties). Field (home gardens, cultivated fields, bushes, shallows) visits were organised in order to observe the plant species under cultivation or in their natural habitat.

\section{Data analysis \\ Data were analysed through descriptive statistics (frequencies, percentages, means, etc.) in order to generate summaries and tables at different levels. To analyse the relationship between villages in}


Table 1: List of the selected sites surveyed and their geographical localisation.

\begin{tabular}{|c|c|c|c|c|}
\hline \multirow[t]{2}{*}{$\mathbf{N}^{\circ}$} & \multirow[t]{2}{*}{ Village names } & \multirow{2}{*}{$\begin{array}{l}\text { Village } \\
\text { code }\end{array}$} & \multicolumn{2}{|c|}{ Geographical localisation } \\
\hline & & & Region & District \\
\hline 1 & Agbodjèdo & S10 & Sud & Allada \\
\hline 2 & Aglamidjodji & $\mathrm{C} 15$ & Centre & Savalou \\
\hline 3 & Agonli-houègbo & C19 & Centre & Zangnanado \\
\hline 4 & Akaradè & W22 & Northwest & Bassila \\
\hline 5 & Akongbéré & $\mathrm{C} 5$ & Centre & Savè \\
\hline 6 & Alédjo & W36 & Northwest & Bassila \\
\hline 7 & Aplahoué & S20 & Sud & Aplahoué \\
\hline 8 & Atawignan & S15 & Sud & Adja-ouèrè \\
\hline 9 & Azowlissè & S11 & Sud & Adjohoun \\
\hline 10 & Badékparou & E25 & Northeast & Parakou \\
\hline 11 & Badjoudè & W18 & Northwest & Ouaké \\
\hline 12 & Banon & $\mathrm{C} 3$ & Centre & Bantè \\
\hline 13 & Bassila & W21 & Northwest & Bassila \\
\hline 14 & Béké & W32 & Northwest & Pehounko \\
\hline 15 & Belléfoungou & W12 & Northwest & Djougou \\
\hline 16 & Bensékou & E30 & Northeast & Kandi \\
\hline 17 & Bétérou & E18 & Northeast & Tchaourou \\
\hline 18 & Birni & W33 & Northwest & Copargo \\
\hline 19 & Bodi & W20 & Northwest & Bassila \\
\hline 20 & Bodjékali & E5 & Northeast & Malanville \\
\hline 21 & Boké & E12 & Northeast & Sinendé \\
\hline 22 & Bonou & S14 & Sud & Bonou \\
\hline 23 & Borodarou & E10 & Northeast & Gogounou \\
\hline 24 & Borondy & W11 & Northwest & Djougou \\
\hline 25 & Copargo & W35 & Northwest & Copargo \\
\hline 26 & Cotiakou & W6 & Northwest & Tanguiéta \\
\hline 27 & Dassari & W25 & Northwest & Materi \\
\hline 28 & Déwa & W15 & Northwest & Djougou \\
\hline 29 & Djaloukou & $\mathrm{C} 7$ & Centre & Savalou \\
\hline 30 & Djougou & W14 & Northwest & Djougou \\
\hline 31 & Doutou & S26 & Sud & Houéyogbé \\
\hline 32 & Dré & S7 & Sud & Houéyogbé \\
\hline 33 & Ewè & S19 & Sud & Kétou \\
\hline 34 & Fita & C8 & Centre & Dassa \\
\hline 35 & Foli & $\mathrm{C} 20$ & Centre & Zakpota \\
\hline 36 & Foumbéa & W13 & Northwest & Djougou \\
\hline 37 & Galata & C14 & Centre & Bantè \\
\hline 38 & Gbassa & E3 & Northeast & Banikoara \\
\hline 39 & Gbêlito & S4 & Sud & Aplahoué \\
\hline 40 & Gbéssaka & E8 & Northeast & Ségbana \\
\hline
\end{tabular}




\begin{tabular}{|c|c|c|c|c|}
\hline 41 & Gokanna & $\mathrm{E} 20$ & Northeast & Tchaourou \\
\hline 42 & Gomé-ifada & $\mathrm{C} 13$ & Centre & Glazoué \\
\hline 43 & Goro & E21 & Northeast & Tchaourou \\
\hline 44 & Gounarou & E11 & Northeast & Gogounou \\
\hline 45 & Goungoun & E7 & Northeast & Kandi \\
\hline 46 & Gouroubéri & E27 & Northeast & Karimama \\
\hline 47 & Guéné & E6 & Northeast & Malanville \\
\hline 48 & Houébossou & S13 & Sud & Lokossa \\
\hline 49 & Hounti & $\mathrm{S} 12$ & Sud & Lokossa \\
\hline 50 & Idadjo & $\mathrm{C} 2$ & Centre & Ouèssè \\
\hline 51 & Ifangni & S25 & Sud & Ifangni \\
\hline 52 & Illara & $\mathrm{S} 21$ & Sud & Kétou \\
\hline 53 & Illikimou & $\mathrm{S} 22$ & Sud & Kétou \\
\hline 54 & Ita akadi & S17 & Sud & Sakété \\
\hline 55 & Kalalé & E17 & Northeast & Kalalé \\
\hline 56 & Kassakpéré & E26 & Northeast & Nikki \\
\hline 57 & Kawado & W17 & Northwest & Ouaké \\
\hline 58 & Konkondji & $\mathrm{C} 16$ & Centre & Savalou \\
\hline 59 & Korontière & W3 & Northwest & Boukoumbé \\
\hline 60 & Kossou-Ouinra & W39 & Northwest & Pehounko \\
\hline 61 & Kouandé & W29 & Northwest & Kouandé \\
\hline 62 & Koundokpoé & S3 & Sud & Comè \\
\hline 63 & Koupagou & W1 & Northwest & Natitingou \\
\hline 64 & Koussoukoingou & W30 & Northwest & Natitingou \\
\hline 65 & Koutagou & W23 & Northwest & Natitingou \\
\hline 66 & Koutakourkou & E29 & Northeast & Kandi \\
\hline 67 & Kpankou & $\mathrm{C} 18$ & Centre & Kétou \\
\hline 68 & Kpanroun & S1 & Sud & Abomey-calavi \\
\hline 69 & Kparou & E13 & Northeast & Tchaourou \\
\hline 70 & Kpassabéga & W34 & Northwest & Kopargo \\
\hline 71 & Lahotan & $\mathrm{C} 17$ & Centre & Savalou \\
\hline 72 & Lou & E15 & Northeast & Kalalé \\
\hline 73 & Louho & $\mathrm{S} 24$ & Sud & Porto-Novo \\
\hline 74 & Madémahoué & S8 & Sud & Come \\
\hline 75 & Magoumi & $\mathrm{C} 12$ & Centre & Glazoué \\
\hline 76 & Malanville & E4 & Northeast & Malanville \\
\hline 77 & Manigri & W38 & Northwest & Bassila \\
\hline 78 & Minifi & $\mathrm{C} 10$ & Centre & Dassa-Zoumè \\
\hline 79 & Monkassa & E28 & Northeast & Malanville \\
\hline 80 & Montèwo & $\mathrm{C} 4$ & Centre & Savè \\
\hline 81 & Nafayaoti & W27 & Northwest & Tanguiéta \\
\hline 82 & Naogon & $\mathrm{S} 23$ & Sud & covè \\
\hline 83 & Naougou & W2 & Northwest & Cobly \\
\hline 84 & Niaro & W31 & Northwest & Kouandé \\
\hline
\end{tabular}




\begin{tabular}{|c|c|c|c|c|}
\hline 85 & Odo mèta & $\mathrm{S} 18$ & Sud & Kétou \\
\hline 86 & Okounfo & $\mathrm{C} 11$ & Centre & Save \\
\hline 87 & Okoutaossé & $\mathrm{C} 1$ & Centre & Bantè \\
\hline 88 & Ouari Maro & E19 & Northeast & N'Dali \\
\hline 89 & Ouèdèmè adja & S6 & Sud & Lokossa \\
\hline 90 & Pam-Pam & W10 & Northwest & Perma \\
\hline 91 & Paouignan & C9 & Centre & Dassa-Zoumè \\
\hline 92 & Parakou & E23 & Northeast & Parakou \\
\hline 93 & Pédarou & E14 & Northeast & Parakou \\
\hline 94 & Pénéssoulou & W37 & Northwest & Djougou \\
\hline 95 & Péporiyakou & W9 & Northwest & Natitingou \\
\hline 96 & Pèrèrè & E16 & Northeast & Pèrèrè \\
\hline 97 & Satiandiga & W24 & Northwest & Tanguiéta \\
\hline 98 & Sébou & E22 & Northeast & Parakou \\
\hline 99 & Sèdjè-Dénou & $\mathrm{S} 2$ & Sud & Abomey-Calavi \\
\hline 100 & Ségbana & E9 & Northeast & Ségbana \\
\hline 101 & Sègbohoué & S9 & Sud & Allada \\
\hline 102 & Sèmèrè & W19 & Northwest & Ouaké \\
\hline 103 & Sinawongourou & E31 & Northeast & Kandi \\
\hline 104 & Sokouhoué & S5 & Sud & Lokossa \\
\hline 105 & Sokponta & C6 & Centre & Glazoué \\
\hline 106 & Sonoumon & E1 & Northeast & N'Dali \\
\hline 107 & Sooum & W4 & Northwest & tanguiéta \\
\hline 108 & Tansé & W28 & Northwest & Kouandé \\
\hline 109 & Tayakou & W7 & Northwest & Tanguiéta \\
\hline 110 & Tchakalakou & W8 & Northwest & Natitingou \\
\hline 111 & Tchaourou & E24 & Northeast & Tchaourou \\
\hline 112 & Tiélé & W5 & Northwest & Tanguiéta \\
\hline 113 & Toubougnidi & W26 & Northwest & Matéri \\
\hline 114 & Toumè & E32 & Northeast & N'dali \\
\hline 115 & Wassa & W16 & Northwest & Djougou \\
\hline 116 & Wiya & $\mathrm{S} 27$ & Sud & Grand-Popo \\
\hline 117 & Yakassou & $\mathrm{E} 2$ & Northeast & N'dali \\
\hline 118 & Zoungbomè & $\mathrm{S} 16$ & Sud & Akpro-Missérété \\
\hline
\end{tabular}

terms of species distribution, surveyed villages (Table 1) were considered as individuals and the vegetable species (Acmella uliginosa, Ceratotheca sesamoides, Justicia tenella and Sesamum radiatum) as variables and scored as 1 when present or 0 when absent. Using this methodology, a binary matrix was compiled and used to perform a Principal Coordinate Analysis (PCA) with SAS statistical package (SAS
Institute, 1996). Similarity between species in term of geographical localisation was assessed using Jaccard coefficient of similarity (Jaccard, 1908) computed by NTSYS-pc 2.2 (Rohlf 2000) and a dendrogram drawn using UPGMA cluster analysis of the same program (Sneath and Sokal 1973; Swofford and Olsen 1990). In this analysis, vegetable species were considered as individuals and the villages as 
variables and scored as described above. For better understanding of the species' ecology, their geographical distribution maps constructed using MapInfo Professional 8.0 were superimposed on the Benin soils and climate maps following Adam and Boko (1993) and the frequency of the species in diverse ecological zones (number of villages in which the species is found out of the total number of the villages surveyed) were determined.

\section{RESULTS}

\section{Origins of the species}

Out of the four leafy vegetables studied, only the uncultivated species Ceratotheca sesamoides is recognised by the farmers as indigenous to the country. According to them, Justicia tenella, Acmella uliginosa and Sesamum radiatum were all introduced to Benin at different periods. Justicia tenella was introduced to the northeast of Benin about 60 years ago by the catholic European missionaries while Acmella uliginosa and Sesamum radiatum were introduced from Togo to the Northwest by Kabiè immigrants, about respectively 10 years and 50 years ago.

\section{Folk nomenclature}

Across the various villages and ethnic groups surveyed, TLVs are identified by specific vernacular names. For the four species investigated, a total of 93 vernacular names were recorded (Table 2). While $C$. sesamoides and $S$. radiatum have the greatest recorded number of vernacular names (29 and 30 respectively), only 15 vernacular names were recorded for J. tenella and 19 for A. uliginosa (Table 2). The meanings of the vernacular names recorded are compiled in Table 2.

Our analysis revealed the use, across regions, of nine key criteria in naming the four species under study. These are: origin, status of the plant (wild, cultivated), specific habitat, growth habit (creeping or erected), shape of the leaf, taste, easiness of the cooking, type and colour of the sauce (Table 1). While five criteria were used to name $S$. radiatum and $C$. sesamoides, only two (origin and taste) were applied to A. uliginosa and all apart from the growth habit go with $J$. tenella. No vernacular names in relation with origin have been used to designate $C$. sesamoides. Taste is only applied to A. uliginosa and J. tenella and it appeared, for these species, as the most used criteria. The slimy aspect of the sauce is the most important criterion used to designate $C$. sesamoides and $S$. radiatum. These two morphologically very close species are separated in their naming by two additional key criteria which are the growth habit (C. sesamoides is creeping while $S$. radiatum is erected) and the status (C. sesamoides is wild while $S$. radiatum is cultivated) of the plant (Table 3).

\section{Geographical distribution and ecology of the species}

The geographical distribution maps of the species (Figures 1) revealed that they are unequally distributed throughout the country. Indeed, A. uliginosa (Figure 1) is found almost exclusively in the northwest region (Departments of Donga and Atakora). $J$. tenella occupies the north and the Nago cultural area of the centre of Benin (Figure 1). $S$. radiatum was found almost everywhere in Benin (Figure 1). Apart from the far south where it is absent (Figure 1) Ceratotheca sesamoides follows the same geographical distribution as $S$. radiatum.

The superimposition of the geographical distribution maps of the species with both Benin soil and climate maps combined with the frequency of occurrence of the species on each type of soil (Figure 2) or climate (Figure 3) helped to understand their respective ecology. C. Sesamoides, although present everywhere, mostly occurs on ferralitic and ferruginous soils (Figure 2) and in Sudanian and Atacorian climates (Figure 3). In almost all the villages surveyed, this species was reported to be closely linked to lateritic soils and some of its vernacular names (Table 2) even refer to this particular habitat. S. radiatum is found on all the types 
Table 2: List of the vernacular names recorded per species and their meaning.

\begin{tabular}{|c|c|c|c|}
\hline Species & Vernacular names & Ethnic groups & Meaning of vernacular names \\
\hline \multirow{29}{*}{$\begin{array}{l}\text { Ceratotheca } \\
\text { sesamoides }\end{array}$} & Abiwèrè & Tchabè & - \\
\hline & Agbô & $\begin{array}{l}\text { Idatcha, Mahi, } \\
\text { Goun, Fon }\end{array}$ & Slimy vegetable \\
\hline & Assôworou & lamba & Slimy vegetable of hare \\
\hline & Dowoungbaana & Boko & Vegetable of rocky zones \\
\hline & Féïyôtô & Dendi & Slimy vegetable \\
\hline & Gandafoï & Dendi & Creeping vegetable \\
\hline & Gnankassounwari & Bariba & Wild vegetable \\
\hline & Goufounin & Ani & Slimy vegetable \\
\hline & Idjabô & Tchabè & Slimy vegetable \\
\hline & Issé & Mokolé & Slimy vegetable \\
\hline & Kasankpokpo & Foodo & Slimy creeping vegetable \\
\hline & Koufoihangou & Gangamba & Wild slimy and creeping vegetable \\
\hline & Koumonkou ilè & Fè & Slimy creeping vegetable \\
\hline & Kpééwari & Bariba & Slimy creeping vegetable \\
\hline & Kpééwori & Bariba & Slimy creeping vegetable \\
\hline & N'zoti adènin & Kotokoli & Creeping and slimy vegetable \\
\hline & Nonman & Wama & Slimy vegetable \\
\hline & Nonpoéa & Wama & White slimy vegetable \\
\hline & Nôr & Pila pila & - \\
\hline & Siwadouanwé & Ditamari & - \\
\hline & Taalè hounnoum & Lokpa & Wild Slimy vegetable \\
\hline & Tanonman & Wama & Creeping and slimy vegetable \\
\hline & Toohoun & Berba & Slimy vegetable \\
\hline & Toopouôguè & Berba & White and slimy vegetable \\
\hline & Toossibouhoun & Berba & Black and slimy vegetable \\
\hline & Wôri & Bariba & Slimy vegetable \\
\hline & Wôrigbéégui & Bariba & Wild vegetable \\
\hline & Woriyô & Peulh & - \\
\hline & Yoodo & Dendi & Slimy vegetable \\
\hline \multirow{14}{*}{$\begin{array}{l}\text { Sesamum } \\
\text { radiatum }\end{array}$} & Agbôè & Aïzô & Slimy vegetable \\
\hline & Agbon & Adja & Slimy vegetable \\
\hline & Agbôté & Idatcha & Erect slimy vegetable \\
\hline & Anansara foïto & Dendi & Slimy sauce of white people \\
\hline & Dossé & Tchabè & - \\
\hline & Dossi / Dossiguia & Bariba & - \\
\hline & Dossiyô & Peulh & - \\
\hline & Dossila & Boko & Black vegetable \\
\hline & Féïyôtô & Dendi & Slimy vegetable \\
\hline & Gooloo & Tchabè & - \\
\hline & Gousséninfounin & Ani & $\begin{array}{l}\text { Slimy vegetable prepared with } \\
\text { potash }\end{array}$ \\
\hline & Koumalo odoussè & Foodo & Slimy cultivated vegetable \\
\hline & Koumalo oyélissè & Foodo & Erect Slimy vegetable \\
\hline & Koumankoun akô & Fè & Male Slimy vegetable \\
\hline
\end{tabular}




\begin{tabular}{|c|c|c|c|}
\hline & Kounanhangou & Gangamba & Slimy vegetable of the people Kabiè \\
\hline & Koussèlomsôgou / & Gnindé & Black slimy vegetable \\
\hline & Koussèlomsô & & \\
\hline & Lakouta & Dendi & - \\
\hline & N'zoti koudouté & Kotokoli & Cultivated slimy vegetable \\
\hline & Ningbô & Mahi & - \\
\hline & Nonbotaman & Wama & Slimy and cultivated vegetable \\
\hline & Nonmanwon & Yom & - \\
\hline & Okoukou & Holi & Slimy vegetable \\
\hline & Sôka wourou & Lamba & Slimy vegetable like sesame \\
\hline & Tankantohoun & Berba & $\begin{array}{l}\text { Slimy vegetable of wama ethnic } \\
\text { group }\end{array}$ \\
\hline & Tébonon & Bariba & - \\
\hline & Titamanwadouanti & Ditamari & Slimy vegetable of Ditamari people \\
\hline & Touhounnoum & Lokpa & Slimy vegetable of elephant \\
\hline & Touwadouanti & Ditamari & Slimy vegetable of elephant \\
\hline \multirow[t]{19}{*}{$\begin{array}{l}\text { Acmella } \\
\text { uliginosa }\end{array}$} & Anansaara kalowao & Lokpa & $\begin{array}{l}\text { Zanthoxylum xanthoxyloides of } \\
\text { white people }\end{array}$ \\
\hline & Boubouô & Ditamari & Vegetable of pepper taste \\
\hline & Boupèbouô & Ditamari & White people's pepper \\
\hline & Bourdierikè & Berba & - \\
\hline & Didakomfroubiali & Gangamba & $\begin{array}{l}\text { Zanthoxylum xanthoxyloides of } \\
\text { Ditamari's ethnic group }\end{array}$ \\
\hline & Djidja koumalo & Foodo & Slimy vegetable of elephant \\
\hline & Gaatam migaate & Peulh & - \\
\hline & Kablè koulmawô & Foodo & Spice of Kabiè's ethnic group \\
\hline & Kalwôou & Lamba & - \\
\hline & Kpékpéraboubou & Berba & - \\
\hline & Kpéssèbohaa & Yom & - \\
\hline & Lôwôlôkpè & Holi & It's on the hands it takes a long time \\
\hline & Otomkalouwè & Ani & $\begin{array}{l}\text { Vegetable of Zanthoxylum } \\
\text { xanthoxyloides' taste }\end{array}$ \\
\hline & Oulakombouonou & Yindé & - \\
\hline & Sããnakpãwõgõ & Pila pila & $\begin{array}{l}\text { White people's Zanthoxylum } \\
\text { xanthoxyloides }\end{array}$ \\
\hline & $\begin{array}{l}\text { Tanwou- } \\
\text { wouroussouguia }\end{array}$ & Bariba & - \\
\hline & Yèyèca & Kotokoli & Taste like pepper \\
\hline & Yoritampobou & Wama & Yoruba vegetable of pepper taste \\
\hline & Yowaboukpé & Bariba & Vegetable of Ditamari ethnic people \\
\hline \multirow{9}{*}{$\begin{array}{l}\text { Justicia } \\
\text { tenella }\end{array}$} & Agbadoudou & Kotokoli ; Foodo & Delicious vegetable \\
\hline & Atchélikéma & Ani & Atchélé tree's vegetable \\
\hline & Bôwénou & Bariba & - \\
\hline & Dimouniountchoro & Wama & $\begin{array}{l}\text { Woman eat and forget to serve her } \\
\text { husband }\end{array}$ \\
\hline & Djagudjagu & Fè, Tchabè & Eat fufu (pounded yam) \\
\hline & Djègoudjègou & Idatcha & Eat fufu (pounded yam) \\
\hline & Gnonwonko & Bariba & - \\
\hline & Kourôkountônu & Bariba & The woman is not the man \\
\hline & & 1365 & \\
\hline
\end{tabular}




\begin{tabular}{lll} 
Parbatoukpékpéya & Wama & Hard leaves \\
Saligaman & Saxwè & Haoussa ethnic group 's vegetable \\
Tchakou tchakou & Lamba & - \\
Tikounsooti & Ditamari & Black vegetable \\
Tilétoussi & Lokpa & Vegetable of termites \\
Tipèwadouanti & Ditamari & Slimy vegetable of white people \\
Tokpélé & Saxwè & - \\
\hline
\end{tabular}

of Benin soils and climates (Figures 2 and 3). A. uliginosa and J. tenella are all associated with the ferralitic and ferruginous soils and with the Sudanian and Atacorien climates of the northern Benin.

\section{Selection of zones for in situ conservation}

The Principal Coordinate Analysis (PCA) carried out to analyse the relationships between surveyed villages in term of species distribution led to four groups, namely G1, G2, G3 and G4 (Figure 4). G1 gathers villages (almost all of the northwest) in which, A. uliginosa was found. G2 is the group of $J$. tenella. This particular group assembles villages in which $J$. tenella is associated with $C$. cesamoides and $S$. radiatum. Groups 3 and 4 identify $S$. radiatum and $C$. Cesamoides respectively. At $75 \%$ of similarity on the dendrogram (Figure 5) which was designed to assess the resemblance between species in term of geographical distribution, $C$. cesamoides and $S$. radiatum were found to cluster together. Moreover, they appeared as isolated from $J$. tenella and A. uliginosa. Geographical distribution of the species combined with multivariate analysis led to the selection of two regions for the in situ conservation of the genetic resources of the species. These are the Northwest for $A$. uliginosa in association with the couple $C$. cesamoides and $S$. radiatum and the Northeast for $J$. tenella together with the same couple.

\section{DISCUSSION}

All the species under study, apart from Ceratotheca sesamoides, were reported as introduced in Benin. Although farmers uphold the thesis of the introduction of Justicia tenella in Benin, its area of origin remains unclear. The species is still not described yet in the PROTA database (www.prota.org) and it is therefore difficult to hypothesise on its origin and history. Acmella uliginosa and Sesamum radiatum effectively exist in Togo and their local geographical localisations, as reported by Batawila et al. (2007), is in agreement with reports from Beninese farmers. The introduction of species or crop varieties from one country to another via the cross border communities is frequent. In Benin, it has been already reported for many crops including fonio (AdoukonouSagbadja et al., 2006; Dansi et al., 2009b), yam (Dansi et al., 1999; Dumont and Vernier, 2000; Mignouna and Dansi, 2003) and leafy vegetables (Dansi et al., 2008a).

Various vernacular names are used to designate the species. Among the 93 vernacular names recorded (Table 2), 24 were already reported by Dansi et al. (2009a). The analysis of the meanings of vernacular names compiled in Table 2 confirms the existence of various scenario which are specific to folk nomenclature (unexplained names, synonymy, homonymy, semantic, same name across ethnic area, singular and plural) as reported by Mekbib (2007) on sorghum and Dansi et al. (2009a) on TLVs. The fact that no vernacular names in relation with origin have been used to designate $C$. sesamoides was expected as C. sesamoides is indigenous and growth in the wild (Akoègninou et al., 2006; Dansi et al., 2009). Taste is the most used criteria in naming A. uliginosa and J. tenella. According to the farmers, A. uliginosa has a particular spicy taste similar to the one of the root's bark of Zanthoxylum xanthoxyloides. One understands why almost all the vernacular names of this species refer to the taste of Zanthoxylum root's bark (Pepper taste) and to its foreign origin as described above (Table 2 ). In the northern regions, both species are rather used as nutraceuticals for the same 


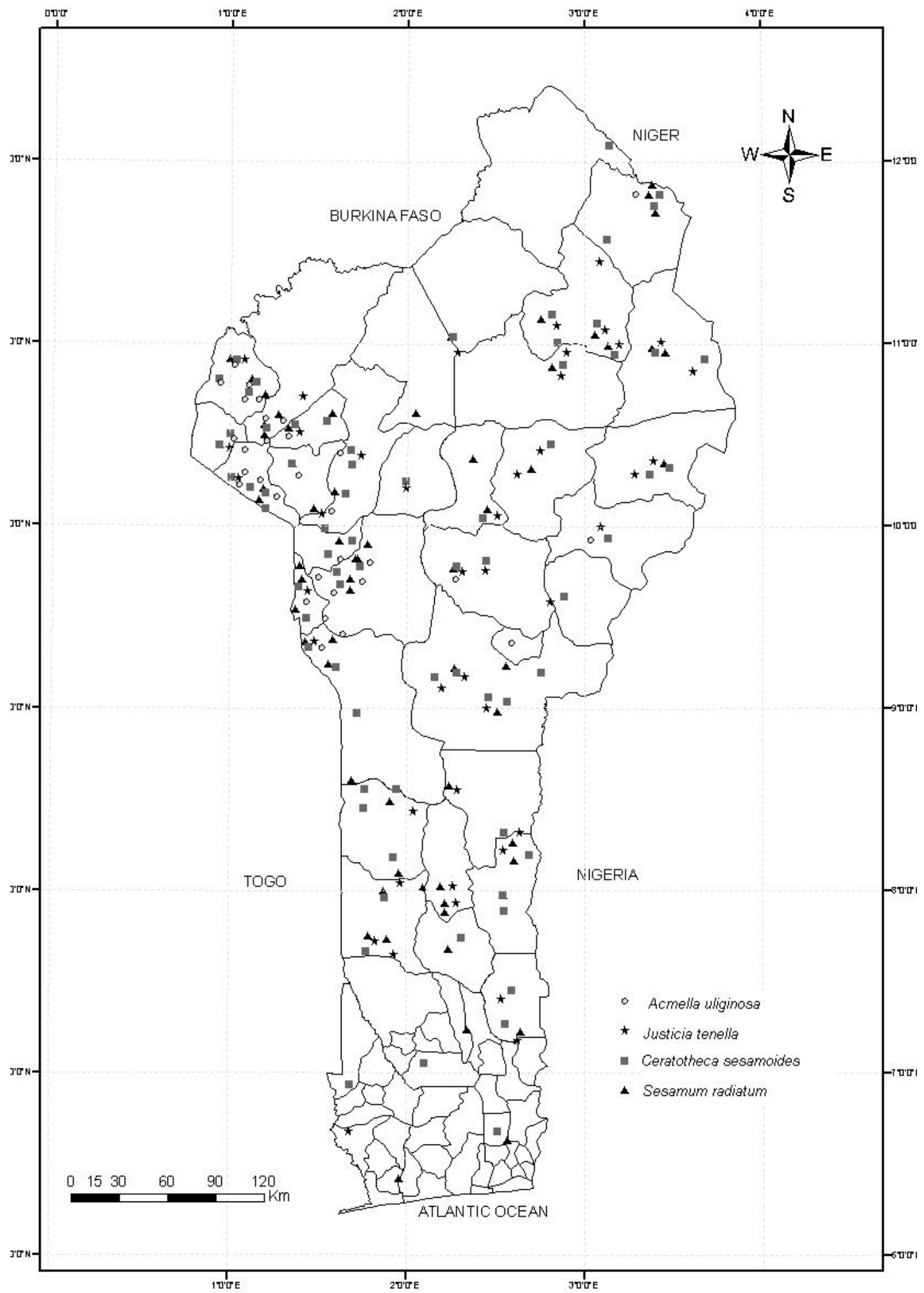

Figure 1: Geographical distribution map of Acmella uliginosa, Ceratotheca sesamoides, Justicia tenella and Sesamum radiatum in Benin. 


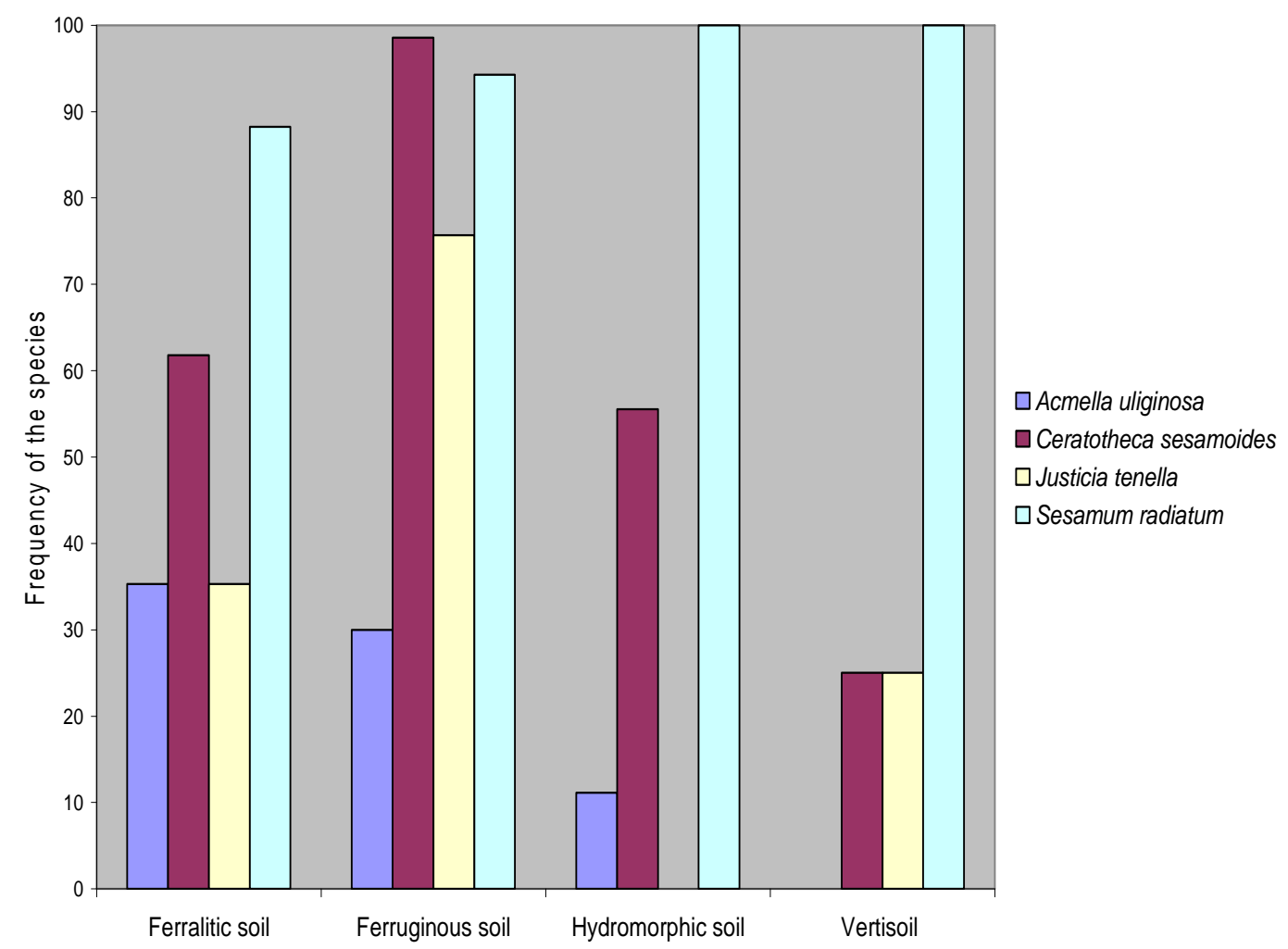

Figure 2: Frequency of the species on different Benin soils.

Table 3: Naming criteria and their importance per species.

\begin{tabular}{lllll}
\hline Criteria & $\begin{array}{l}\text { C. sesamoides } \\
(\%)\end{array}$ & $\begin{array}{l}\text { S. radiatum } \\
(\%)\end{array}$ & $\begin{array}{l}\text { J. tenella } \\
(\%)\end{array}$ & $\begin{array}{l}\text { A. uliginosa } \\
(\%)\end{array}$ \\
\hline Origin & - & 10.52 & 12.5 & 46.66 \\
Taste & - & - & 50 & 53.34 \\
Aspect of the sauce & 60.86 & 55.26 & 6.25 & - \\
Status of the plant & 10.86 & 18.42 & 6.25 & - \\
Specific habitat of the & 02.17 & - & 6.25 & - \\
plant & & & & \\
Growth habit & 19.56 & 7.89 & - & - \\
Colour of the sauce & 6.52 & 7.89 & 6.25 & - \\
Shape of the leaf & - & - & 6.25 & - \\
Easiness of the cooking & - & - & 6.25 & - \\
\hline
\end{tabular}

N.B.: For a given species and criterion, value in the table represents percentage of vernacular names based on the criteria. 


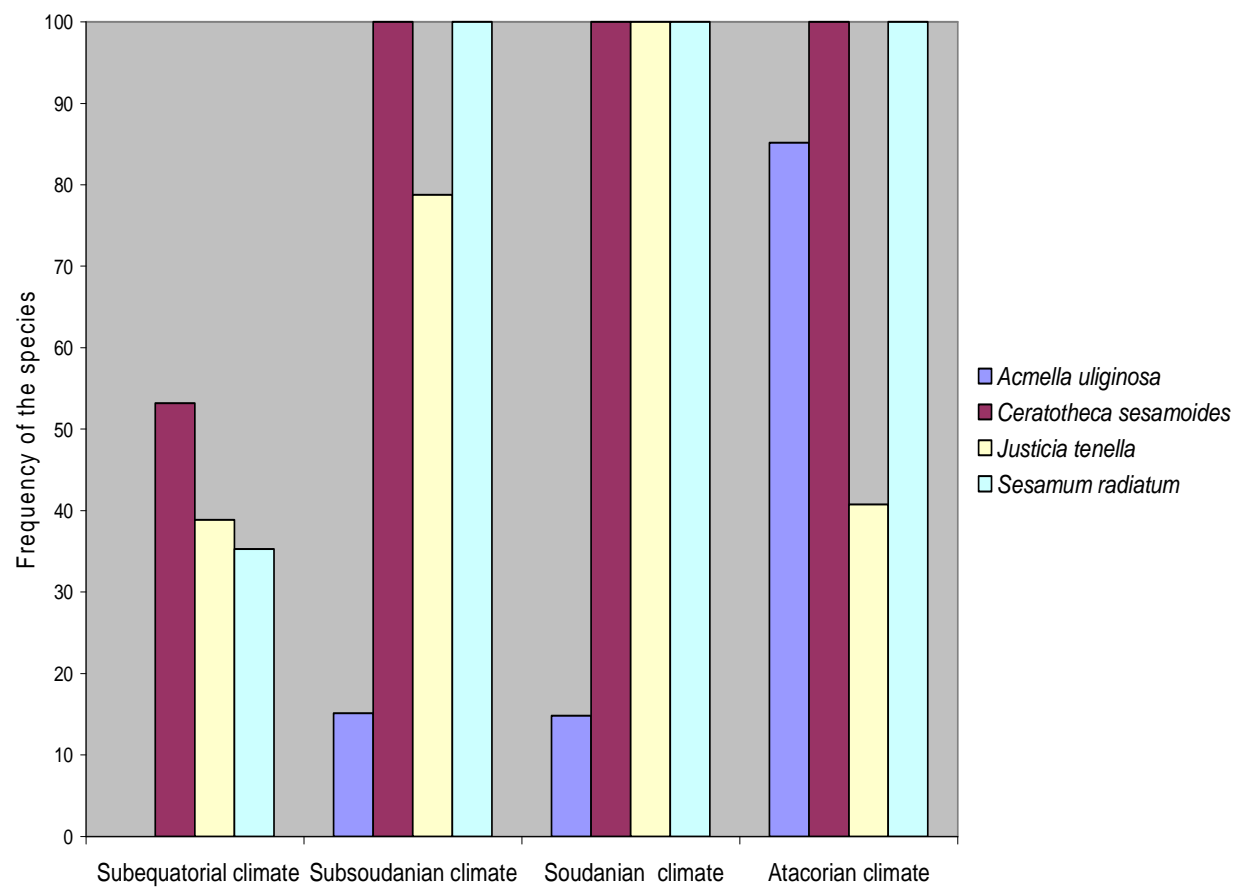

Figure 3: Frequency of the species on different Benin climates.

purposes (Akoègninou et al., 2006; Dansi et al., 2008a). In the case of $J$. tenella the taste really refers to the deliciousness of its sauce which most frequently brings women (as reported by interviewed men) to eat all and therefore forget to reserve a part for their husbands. Its vernacular names Dimounin'tchoro and Kourôkountonnou which literally mean "a woman has forgotten to give to her husband" and "a woman is not a man" in Wama and Bariba languages respectively are in agreement with the men's statement. As reported by many authors (Brush 1980; Brush et al., 1981; Alcorn 1984; Hernandez 1985; Maxted et al., 1997; Brush, 2000; Tuan et al., 2003) the understanding of folk nomenclature of these species helps in identifying their importance and distribution and consequently in developing appropriate in situ conservation strategies.

As revealed by the geographical distribution map, the four species under study are unequally distributed throughout the country. According to farmers, the presence of
Acmella iluginosa in some places in the northeast (Parakou, Malanville, Sonoumon and Kassakpèrè) is linked to the migration of some Ditamari farmers from the northwest in the search of labour opportunities. The fact that this species is sold exclusively by the Ditamari women in the local markets of these localities confirms this hypothesis. J. tenella which was firstly known and used by the Bariba people of the northeast has rapidly diffused toward the northwest and the centre. The historic mixture and the remarkable integration of the Nago and Bariba communities in the transition zone of Tchaourou have surely contributed to its quick adoption as a leafy vegetable by Nago people. The absence of the species in the Mahi cultural area though surrounded by Nago was surprising and needs further investigation. The results obtained in this study with regard to the ecology (soil and climate) of $C$. sesamoides and Sesamum radiatum are in agreement with those reported by Bedigian (2004) and Batawila et al. (2007). A. uliginosa 


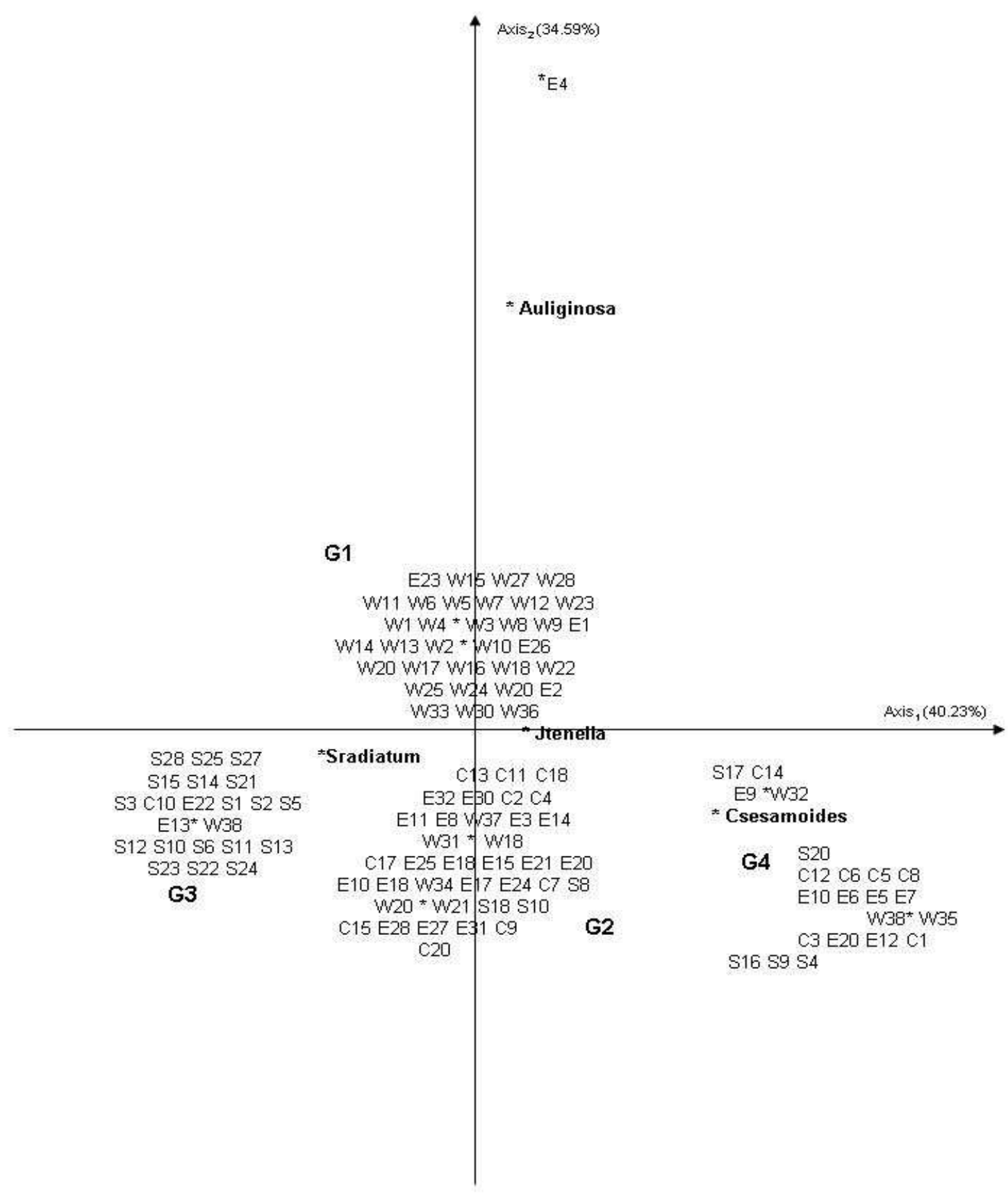

Figure 4: Principal Coordinate Analysis showing the dispersion of the surveyed villages with regard to the presence of the species under study. Villages grouped together are similar by the species they contain. 

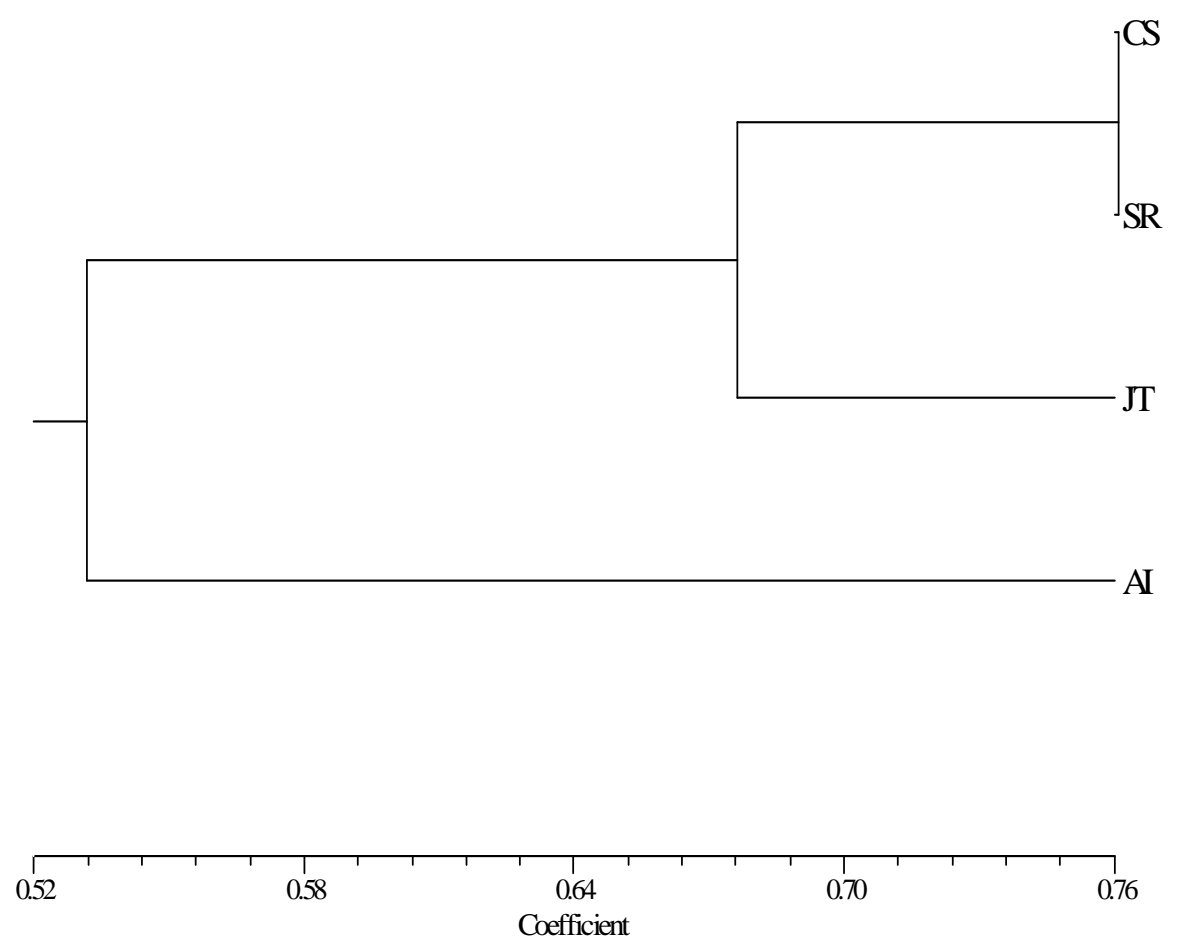

Figure 5: UPGMA dendrogram based on Jaccard coefficient of similarity showing the grouping of the species. CS (Ceratotheca sesamoides), SR (Sesamum radiatum), JT (Justicia tenella), AI (Acmella uliginosa).

is actually in progression towards the centre, the south and the northeast. It is also the case of $J$. tenella which is in progression towards the south. For these two cultivated species, it is too early to conclude on their final distribution and ecology mainly because of their continuous spread.

The results of the multivariate analysis combined with the geographical distribution of the species have led to the selection of the northwest and of the northeast for the in situ conservation of the genetic resources. However, as $C$. cesamoides and $S$. radiatum are not distributed only in the north, their adaptability to various agro-ecological zones could also reflect some fractionation of their respective total genetic diversity. Therefore, a further genetic diversity assessment using molecular markers is required for the estimation of genetic diversity and the selection of adequate conservation sites for these two species as it was the case for Dioscorea abyssinica (Agbangla et al., 2007), Digitalis obscura (Nebauer et al., 1999) and Asimina triloba (Huang et al., 2000). Following Maxted et al. (1997), two to three sites should be chosen within selected regions as conserving diversity in many sites is not only more reassuring but highly recommended.

\section{Conclusion}

The present study revealed that the four species under study are unequally distributed throughout the country and are preferentially linked to diverse soils and climates. Therefore, more than one zone will be required to preserve genetic resources in 
situ. Based on both distribution maps and multivariate analysis, Northwest and Northeast regions were selected as appropriate conservation zones for A. uliginosa and $J$. tenella respectively. At the same time, these two zones will also help to conserve $S$. radiatum and $C$. sesamoides which are present almost everywhere in Benin. Because of the wide adaptability of these two closely related species to various agro-ecological zones, the existence of a well structured but hidden intraspecies genetic diversity has been hypothesized. Estimating this genetic diversity using molecular markers such as AFLP will be useful in decision making with regard to the selection of additional in situ conservation sites.

\section{ACKNOWLEDGEMENTS}

This research was sponsored by the scientific council of the University of Abomey-Calavi (UAC) through the collaborative project "6 AVG" on Traditional Leafy Vegetables. We thank Dr $\mathrm{H}$. Yédomonhan (Department of Botany, FAST) for his technical assistance during the entire study and $\mathrm{Mr}$ A. Onansanya (WARDA, Cotonou, Benin) for help with both SAS and NTSYS computer programs. We are also grateful to all the communities or individual farmers we met for fruitful discussions during the surveys.

\section{REFERENCES}

Abukutsa-Onyango MO. 2004. Crotalaria brevidens Benth. In Plant Resources of Tropical Africa 2. Vegetables, Grubben GJH, Denton OA (eds). Backhuys Publichers: Leiden, Wageningen/CTA, Netherlands; 229-231.

Adam S, Boko M. 1993. Le Bénin. Les Editions du Flamboyant / EDICEF.

Adoukonou-Sagbadja H, Dansi A, Vodouhè R, Akpagana K. 2006. Indigenous knowledge and traditional conservation of Fonio millet (Digitaria exilis Stapf, Digitaria iburua Stapf) in Togo.
Biodiversity and Conservation, 15: 23792395.

Agbangla C, Dansi A, Ahanhanzo C, Alavo TBC, Daïnou O, Tostain S, Scarcelli N, Pham J-L. 2007. Assessment of genetic diversity within and between populations of Dioscorea abyssinica Hochst. ex Kunth of northern Benin using AFLP (Amplified Fragment Length polymorphism) markers. Annales des Sciences Agronomiques du Bénin, 9(1): 43-55.

Akoègninou A, Van der Burg WJ, Van der Maesen LJG. 2006. Flore Analytique du Bénin. Backhuys Publishers: Netherlands.

Alcorn JB. 1984. Huastec Mayan Ethnobotany. Austin, Univ. Press : Texas.

Batawila K, Akpavi S, Wala K, Kanda M, Vodouhè R, Akpagana K., 2007. Diversité et gestion des légumes de cueillette au Togo. AJFAND, 7(3): 1-16.

Bedigian D. 2004. Slimy leaves and oily seeds: Distribution and use of wild relatives of sesame in Africa. Economic Botany. 58: 3-33.

Brush SB, Carney HJ, Haumam Z. 1981. Dynamics of Andean potato agriculture. Economic Botany, 35: 70-85.

Brush SB. 1980. Potato taxonomies in Andean agriculture. In Indigenous Knowledge Systems and Development, Brokensha DW, Warren DM, Werner O (eds). University Press of America: New York; 37-47.

Brush SB. 2000. Genes in the Field. Lewis Publishers: United Kingdom.

Chweya JA, Eyzaguirre P. 1999. The Biodiversity of Traditional Leafy Vegetables. IPGRI Publication: Italy.

Dansi A, Adjatin A, Adoukonou-Sagbadja H, Adomou A, Faladé V, Yedomonhan H, Akpagana K, de Foucault B. 2009a. Traditional leafy vegetables in Benin: Folk nomenclature, species under threat and domestication. Acta Botanica Gallica, 156(2): 183-1999. 
Dansi A, Adjatin A, Adoukonou-Sagbadja H, Faladé V, Yédomonhan H, Odou D, Dossou B. 2008a. Traditional leafy vegetables and their use in Benin Republic. Genetic Resources and Crop Evolution, 55: 1239-1256.

Dansi A, Adoukonou-Sagbadja H, Vodouhè R. 2009b. Diversity, conservation and related wild species of Fonio millet (Digitaria spp.) in the northwest of Benin. Genetic Resources and Crop Evolution (submitted).

Dansi A, Mignouna HD, Zoundjihekpon J, Sangare A, Asiedu R, Quin FM. 1999. Morphological diversity, cultivar groups and possible descent in the cultivated yams (Dioscorea cayenensis-Dioscorea rotundata complex) of Benin Republic. Genetic Resources and Crop Evolution, 46: 371-388.

Dansi, A, Adjatin A, Adoukonou-Sagbadja H, Akpagana K. 2008b. Production and traditional seeds conservation of leafy vegetables in Benin rural areas. Bulletin de la Recherche Agronomique du Benin, 59: 59-70.

Defoer T, Kamara A, de Groove H. 1997. Gender and variety selection: farmers' assessment of local maize varieties in southern Mali. African Crop Sciences Journal, 5(1): 65-76.

Dumont R, Vernier PH. 2000. Domestication of yams (Dioscorea cayenensisrotundata) within the Bariba ethnic group in Benin. Outlook on Agriculture, 29(2): 137-142.

Francisca IS, Eyzaguirre P. 2007. African leafy vegetables: their role in the world health organization's global fruit and vegetables initiative. AJFAND, 7(3): 117.

Hernandez XE. 1985. Maize and man in the greater southwest. Economic Botany, 39(4): 416-430.

Huang HW, Layne DR, Kubisiak TL. 2000. RAPD inheritance and diversity in pawpaw (Asimina triloba). J. Am. Soc. Hort. Sci., 125: 454-459.

Jaccard P. 1908. Nouvelles recherches sur la distribution florale. Bull. Soc. Vaudoise Sci. Nat., 44: 223-270.

Kamara A, Defore T, de Groove H. 1996. Selection of new varieties through participatory research: the case of corn in South Mali. Tropicultura, 14(3): 100-105.

Maxted N, Ford-Lloyd BV, Hawkes JG. 1997. Plant Genetic Conservation: the in situ Approach. Chapman and Hall: United Kingdom.

Mekbib F. 2007. Infra-specific folk taxonomy in sorghum (Sorghum bicolor (L.) Moench) in Ethiopia: folk nomenclature, classification, and criteria. Journal of Ethnobiology and Ethnomedicine, 3(8): 645-663.

Mensah J K, Okoli R I, Ohaju-Obodo J O, Eifediyi K. 2008. Phytochemical, nutritional and medical properties of some leafy vegetables consumed by Edo people of Nigeria. African Journal of Biotechnology, 7(14): 2304-2309.

Mignouna HD, Dansi A (2003). Yam (Dioscorea spp.) domestication by the Nago and Fon ethnic groups in Benin. Genet. Resourc. Crop Evol, 50: 519-528.

Nebauer SG, del Castillo-Agudo L, Segura J. 1999. RAPD variation within and among natural populations of outcrossing willow-leaved foxglove (Digitalis obscura L.). Theor. Appl. Genet., 98: 985-994.

Odhav B, Beekrum S, Akula Us, Baijnath. H. 2007. Preliminary assessment of nutritional value of traditional leafy vegetables in KwaZulu-Natal, South Africa. Journal of Food Composition and Analysis, 20(5): 361-448.

Rohlf FJ. 2000. NTSYS-pc version 2.2: Numerical Taxonomy and Multivariate Analysis System. Exeter Software, New York.

SAS. 1996. SAS/STAT User's guide. Release 612 Cary, N.C SAS Institute. 
Shippers RR. 2002. African indigenous vegetables: an overview of the cultivated species. Chatham, UK. Natural resources Institute/ACP-UE Technical Centre for Agricultural and rural Cooperation.

Sneath PHA, Sokal RO. 1973. Numerical Taxonomy. Freeman: San Francisco.

Swofford DL, Olsen GJ. 1990. Phylogeny reconstruction. In Molecular Systematic, Hillis DM, Moritz C (eds). Sinauer Associates, Sunderland, Mass.
Tuan HD, Hue NN, Sthapit BR, Jarvis DI. 2003. On-farm management of agricultural biodiversity in Vietnam. Proceedings of a Symposium 6-12 December 2001, Hanoi, Vietnam. IPGRI Publication, Italy.

White F. 1993. The AETFAT chorological classification of Africa: history, methods and applications. Bull. Jard. Bot. Natl. Belg., 62: 225-281. 